\title{
Plankton Community in the Pelagic and Littoral Zones of the Overgrown Lake Beloe (Volzhsko-Kamskiy Biosphere Natural State Reserve, Republic of Tatarstan, Russian Federation)
}

\author{
Oksana V. Mukhortova ${ }^{\text {**, }}$ \\ Svetlana V. Bykova ${ }^{a}$, Natalia G. Tarasova ${ }^{a}$, \\ Elena N. Unkovskaya ${ }^{b}$ and Sergey E. Bolotov ${ }^{\mathfrak{c}}$ \\ ${ }^{a}$ Institute of Ecology of the Volga River Basin RAS \\ 10 Komzina, Togliatti, 445003, Russia \\ ${ }^{b}$ Volzhsko-Kamskiy Biosphere Natural State Reserve \\ Sadovyi, Raifa, Zelenodolskiy District, \\ Republic of Tatarstan, 422537, Russia \\ c Institute for Biology of Inland Waters RAS \\ Borok, 152742, Russia
}

Received 16.10.2014, received in revised form 20.12.2014, accepted 09.02.2015

Comparative analysis of different groups of the planktonic community (phytoplankton, protozoo- and zooplankton) was performed in the pelagic and littoral zones of overgrown Lake Beloe (VolzhskoKamskiy Biosphere Natural State Reserve, Republic of Tatarstan, Russain Federation). We detected a remarkable diversity of both pelagic and sublittoral plankton. The planktonic community of the macrophyte zone differs from the community of pelagic zone in a species composition and in larger species diversity.

Keywords: protozooplankton, zooplankton, phytoplankton, planktonic community, abundance, biomass, macrophytes.

(C) Siberian Federal University. All rights reserved

* Corresponding author E-mail address: muhortova-o@mail.ru 


\title{
Характеристика планктонного сообщества
}

пелагической и литоральной зоны

зарастающего мезотрофного озера Белое

\section{(Волжско-Камский биосферный природный}

государственный заповедник, Республика Татарстан)

\author{
О.В. Мухортова ${ }^{\text {**, С.В. Быкова }}$, \\ Н.Г. Тарасова ${ }^{\text {a }}$ Е.Н. Унковская ${ }^{\tilde{\sigma}}$, С.Э. Болотов ${ }^{\mathrm{B}}$ \\ ${ }^{a}$ Институт экологии Волжсккого бассейна РАН \\ Россия, 445003, Тольятти, ул. Комзина, 10
}

${ }^{6}$ Волжскко-Камский государственный природныий биосферный заповедник, Россия, 422537, Республика Татарстан, Зеленодольский район, n. Садовый ${ }^{8}$ Институт биологии внутренних вод им. И.Д. Папанина РАН Россия, 152742, n. Борок

\begin{abstract}
Проведен сравнительныцй анализ развития планктонных организмов (фито-, зоо-, протозоопланктон) в пелагической и литоральной зоне зарастающего озера Белого (Волжско-Камский биосферный природный государственный заповедник, Республика Татарстан). Показано, что в макрофитах все компоненты планктонного сообщества отличаются большим, по сравнению с пелагиалью, видовым богатством и значительной видоспецифичностью. Отмечено значительное различие состава пелагического и зарослевого планктона. Планктонные сообщества водной толщи, обитающие в зарослях различных видов макрофитов, отличались меньше.
\end{abstract}

Ключевые слова: протозоопланктон, фитопланктон, зоопланктон, планктонное сообщество, численность, биомасса, макрофиты.

\section{Introduction}

The littoral zone of a lake is known to be an area with a specific complex of conditions that influences the entire lake ecosystem (Nurminen, 2003; Carpenter et al., 1992; Schindler et al., 1996). Macrophytes are an important component in regulating the biological structure of a lake (Timms, Moss, 1984; Schriver et al., 1995). Macrophytes influence organism distribution in a lake (Durte et al., 1986; Moddelboe, Markager, 1997), light transmission, temperature and $\mathrm{pH}$ (Dale, 1986; Duarte et al., 1986; Vant et al., 1986, 1995, 1996; Lodge, 1991).
Macrophyte occurrence in a lake and degree of its overgrowth show trophic conditions of a lake (Schulthorpe, 1967; Toivonen, Huttunen, 1995). Complex relations between planktonic organisms and between planktonic organisms and macrophytes are a subject matter and a basis for making hypothesis and theories for different scientists (Scheffer et al., 1993, 1992; Jeppesen et al., 1998).

Usually, sublittoral planktonic community in the macrophyte zone differs from that in the pelagic zone of a water body and consists of truly planktonic as well as of 
the periphytic and benthonic species (Barko, James 1999; Karabin, 1985; Lauridsen et al., 1996; Persson, 1991). Macrophytes form a community habitat and establish development peculiarities of all groups of planktonic community (particularly, protozoo-, zooand phytoplankton) in a littoral zone of a lake with macrovegetation (Nurminen et al., 2001). The problem of planktonic organisms development in macrovegetation is not limited to clearing up differences in biodiversity indicators in various biotopes for diverse planktonic components, but it also involves a study of interaction between macrovegetation and planktonic community as a whole. The interaction is reflected by a competition, by displacing a competitor in space, light interception (shading) or nutrient interception (intensive absorption), by allelopathic influence (Fairchild, 1981; Lauridsen et al., 1997; Nabivaiylo, Titlyanov, 2006; Nurminen, 2003), by interspecific competition of zooplankton in macrovegetation, by influence of invertebrate predators inter-connected with macrovegetation on zooplankton (Horppila, Nurminen, 2001, 2003; Semenchenko, 2006). Besides, this interaction affects structural and productional indicators of the whole planktonic community.

The first stage in research of any problem (particularly, revealing of interaction mechanism) consists of data accumulation. In this instance, phyto -, protozoo - and zooplankton are researched in various ecotopes diverse in mineralization, chemical structure, the extent of overgrowth and morphometry of various lakes. This work presents the results of the first planktonic community research in macrovegetation of Lake Beloe. The study is intended to identify peculiarities of planktonic community development (as a whole and its separate components), comparing a pelagic part of basin with a littoral one and associations formed by particular macrovegetation species.

\section{Materials and methods}

Study site

Lake Beloe $\left(55^{\circ} 55^{\prime} 26.2^{\prime \prime} \mathrm{N}, 48^{\circ} 45^{\prime} 49.9^{\prime \prime} \mathrm{E}\right)$ is located in a protected zone of the Raifskiy area of Volzhsko-Kamskiy State Natural Biospheric reserve, Republic of Tatarstan, Russian Federation. It is located in a hydrosystem of the rivers Sumka and Ser-Bulak, located in a karstsuffosion valley (Fig. 1).

Lake Beloe is a water body of karst-suffosion origin, overgrown (30\% of its area is occupied by macrophytes located along the coastal zone). Water retention time in the lake is high, its maximum depth of $4 \mathrm{~m}$, which is found in the south-eastern part of the lake (Fig. 2). The lake length is about $557 \mathrm{~m}$ and its width is about 170 $\mathrm{m}$. At the sampling time, the lake was thermally stratified with a thermocline at the depth of 2-3 $\mathrm{m}$. Water transparency was up to $1.4 \mathrm{~m}$ and water colour value was low $\left(80^{\circ} \mathrm{Pt}\right)$.

Lake water has medium level of mineralization and belongs to calciumhydrocarbonate type. In 2006, a surface layer was oxygen saturated (up to $168 \%$ ), while we revealed a saturation deficit ( $8.7 \%$ ) at the bottom. The following macrophytes are located in the $10 \mathrm{~m}$ width littoral zone: Typha latifolia L., Zizania latifolia Stapf. and Sagittaria sagittifolia L. A shallow part of the lake, with a depth of less than $1 \mathrm{~m}$, is covered by Ceratophyllum demersum L., Elodea canadensis Michx., Potamogeton angustifolius J.Presl and Nuphar lutea L.

\section{Sampling}

Our study of the planktonic community (phyto-, zooplankton, ciliates) was conducted in July of 2006 in six different biotopes: a) a water column in the pelagic part, and b) in a macrovegetation, belonging to different 


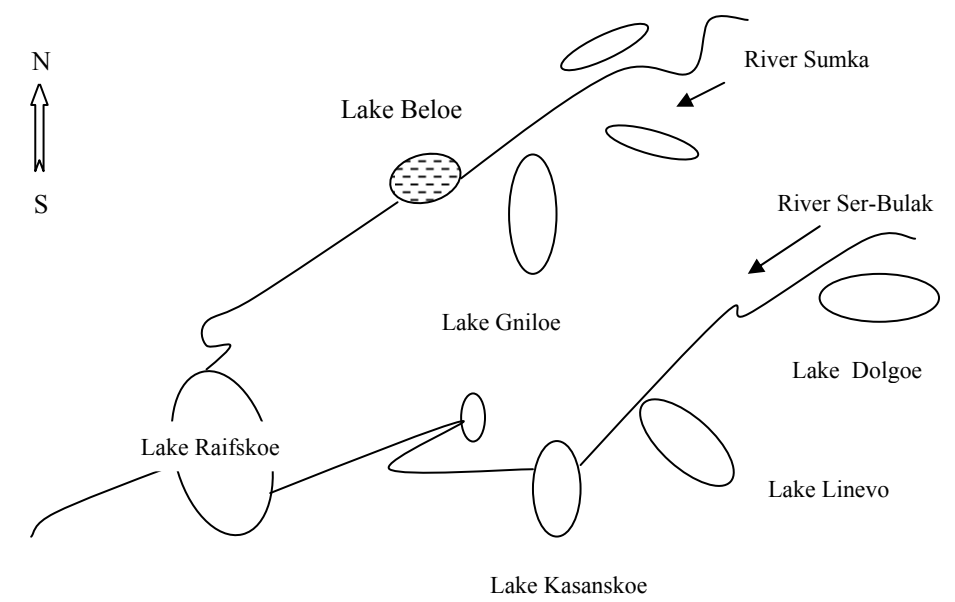

Fig. 1. System of lakes located in the protective zone of Raifskiy area of the Volzhsko-Kamskiy State Natural Biospheric reserve, Republic of Tatarstan, Russia

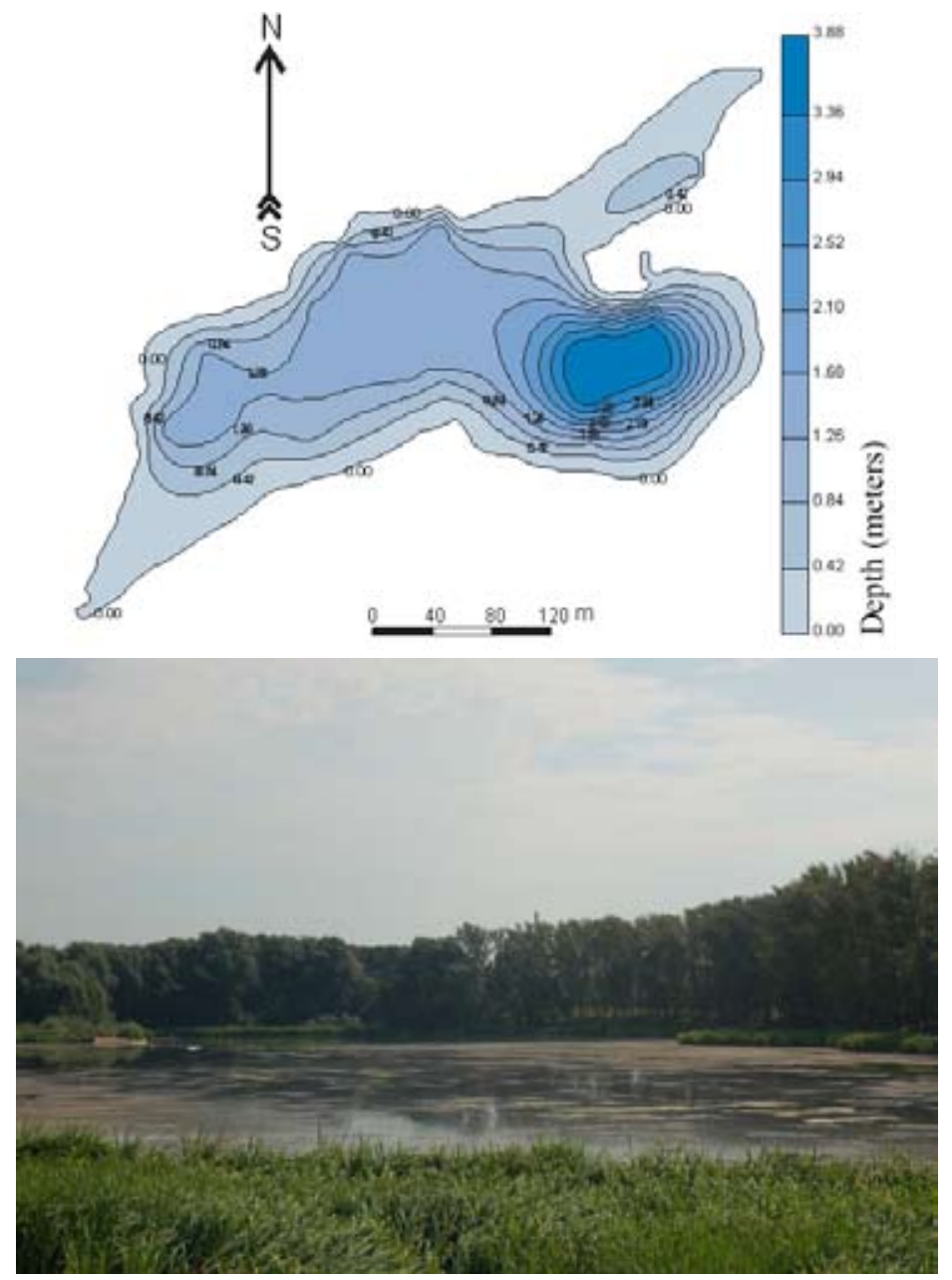

Fig. 2. Bathymetric map and photo of Lake Beloe 
ecological types (Papchenkov, 2006): helophyte tall grass (Z. latifolia) and helophyte low-grass (S. sagittifolia), submerged rooted hydrophytes (C. demersum and $P$. angustifolius) and rooted hydrophytes with floating leaves (N. lutea).

Samples were collected with Ruttner bathometer $(4 \mathrm{~L})$. In macrophyte beds water was sampled from a surface layer $(0.1-0.3 \mathrm{~m})$. In the pelagic zone samples for phyto- and protozooplankton analyses and zooplankton analyses were taken from a surface layer (0.1-0.3 $\mathrm{m})$ and from the whole water column (0-4 m), respectively.

\section{Phytoplankton analysis}

Phytoplankton was concentrated by filtering $0.5 \mathrm{~L}$ of sample through membrane filters of $1 \mu \mathrm{m}$ pore diameter using Komovskiy pump and fixed in $4 \%$ formalin. Cells calculation was made in Uchinskaya chamber ( $0.01 \mathrm{ml}$ volume). Algae biomass was determined with geometric figures method (Kouzmin, 1984). Algae identification was made using standard guidebooks from the series "Susswasserflora von Mitteleuropa" (Ettl, 1983; Ettl, Gartner, 1983; Ettl et al., 1990; Hellawell, 1986; Husted, 1939; Krammer, Lange-Bertalot, 1986, 1988, 1991a, 1991b; Komarek, Anagnostidi, 2000; Popovsky, Pfiester, 1990; Starmach, 1985; Systematik und Biologie, 1983).

\section{Protozooplankton analysis}

Only ciliates from the group of protozoa were studied in this research. Ciliates were identified in alive state, or using samples fixed with mercury chloride $\left(\mathrm{HgCl}_{2}\right)$ and in vapors of osmium. We also used impregnation by silver nitrate $\left(\mathrm{AgNO}_{3}\right)$ (Chatton, Lwoff, 1936) and Feulgen nuclear staining. For species identification we used guide books as well as different papers (Corliss, 1979; Curds et al., 1982, 1983; Foissner et al., 1991, 1999; Kahl, 1931-1935). Counting of planktonic ciliates was performed after concentration 300 $\mathrm{ml}$ of a sample (Mamaeva, 1979) and its fixation with saturated solution of mercury chloride $\left(\mathrm{HgCl}_{2}\right)$. The results were generalized according to taxonomic system of E.B. Small and D.H. Lynn (1985, 2000), taking into consideration other literature sources (Yankovski, 2007). The trophic groups of ciliates were determined based on Pratt and Cairns (1985), Mamayeva (1979) and Zharikov (1996).

\section{Zooplankton analysis}

For zooplankton analysis we concentrated $5 \mathrm{~L}$ of water by filtering it through Apstein net of $64 \mu \mathrm{m}$ mesh size. Zooplankton samples were fixed with $4 \%$ formalin and counted in the Bogorov chamber. Abundance (ind./L) and biomass $\left(\mathrm{mg} / \mathrm{m}^{3}\right)$ were calculated for each species in each sample. The tables of standart weights of organisms (Morduhay-Boltovskoy, 1954) and our measurements were used to calculate the biomass. The average length of the body was converted to weight by method of Vinberg (1971) and Balushkina \& Vinberg (1979). The guide books of Kutikova (1970, 2005), Manuylova (1964), Smirnov (1976, 1996) and OrlovaBienkowskaja (2001) were used for identification of the zooplankters.

\section{Data analysis}

In every group (phytoplankton, protozooplankton, zooplankton) we considered as dominant species those with abundance and biomass not less than $10 \%$ of a total abundance and biomass (Belova, 1998).

Species diversity was evaluated using Shannon index (Odum, 1975):

$$
H=\sum_{i}^{W}\left[\left(\frac{N i}{N}\right) \log _{2}\left(\frac{N i}{N}\right)\right]
$$

where: $N i$ - the abundance of species $(i) ; N$ - the total abundance of all species $(W)$. 
Pielou index was used for confirmation of species community equitability on abundance:

$$
\mathrm{E}=\mathrm{H} / \log \mathrm{N}
$$

where $\mathrm{N}$ - species community abundance in biocenosis (Odum, 1975).

Similarity of the planktonic communities in different ecotopes was calculated with Sørensen's similarity coefficient:

$$
K s=\frac{2 c}{a+b}
$$

where $a$ - the number of species in the first ecotope, $b$ - the number of species in the second ecotope, $c$ - the number of species common to both ecotopes (Odum, 1975).

Stand Density Index (SDI) was calculated for each species in community. SDI is the criteria, connecting average biomass $(B)$ and the abundance of individuals $(N)$, characterizing species inside of biocoenosis (Dedyu, 1989):

$$
S D I=\sqrt{N B}
$$

To study the variations of plankton community, a principal component analysis (PCA) was conducted. A PCA was made for the total community on the basis of Stand Density Index.

Cluster analysis was made using Sørensen's similarity coefficient for planktonic communities in different ecotopes. Clustering of data was made by Ward method, euclidean distance was used as grouping parameter.

Statistical analysis (data clusterization and factor analysis) of the results was made using Statistica software, version 6.0 (StatSoft Inc., USA).

Plotting of a bathymetric map of the Lake Beloe was executed in the program Surfer 12 (Golden Software Inc., USA).

\section{Results and discussion}

Species diversity and species specificity of planktonic community in different biotopes

In 2006 in all biotopes we found 116 species of phytoplankton, 57 species of protozooplankton and 84 species of zooplankton (taking into account phyto- and protozooplankton inhabiting a surface layer of the pelagic zone and zooplankton inhabiting the whole water column of the pelagic zone). Among them, $17 \%$ of phytoplankton species, $14 \%$ of ciliate species and $18 \%$ of zooplankton species were unique for pelagic zone and $47 \%$ of phytoplankton species, $68 \%$ of ciliate species and $60 \%$ of zooplankton species were unique for the macrophyte zone. Similarities between pelagic and macrophyte zones were $55 \%$ for phytoplankton community, $30 \%$ for ciliates and $35 \%$ for zooplankton community. Sørensen's coefficients indicated low similarity between plankton inhabiting pelagic zone and communities of different sublittoral ecotopes (34$45 \%$ - for phytoplankton, $12-19 \%$ - for ciliate, $45-57 \%$ - for zooplankton). From the other side, similarity between plankton communities inhabiting different macrophyte species beds was high (43-66 \% - for phytoplankton, 55-68 \% for ciliate, 44-50 \% - for zooplankton). Cluster analysis indicated the peculiarity of pelagic plankton; and the community from Nuphar was the closest to the pelagic one among the sublitoral ecotopes (Fig. 3). Species diversity of zooplankton (Shannon index based on abundance $\mathrm{Hn}=4.59$; Pielou index $\mathrm{E}=0.84)$ and phytoplankton $(\mathrm{Hn}=$ 4.76; $\mathrm{E}=0.78$ ) community was higher in the zone of submerged rooted macrophytes (Ceratophyllum and Potamogeton). Shannon index was high due to a high number of species and a relatively low number of dominant species (or even their absence) (Table 1).

Only two dominants were registered in the phytoplankton community of $P$. angustifolius - 


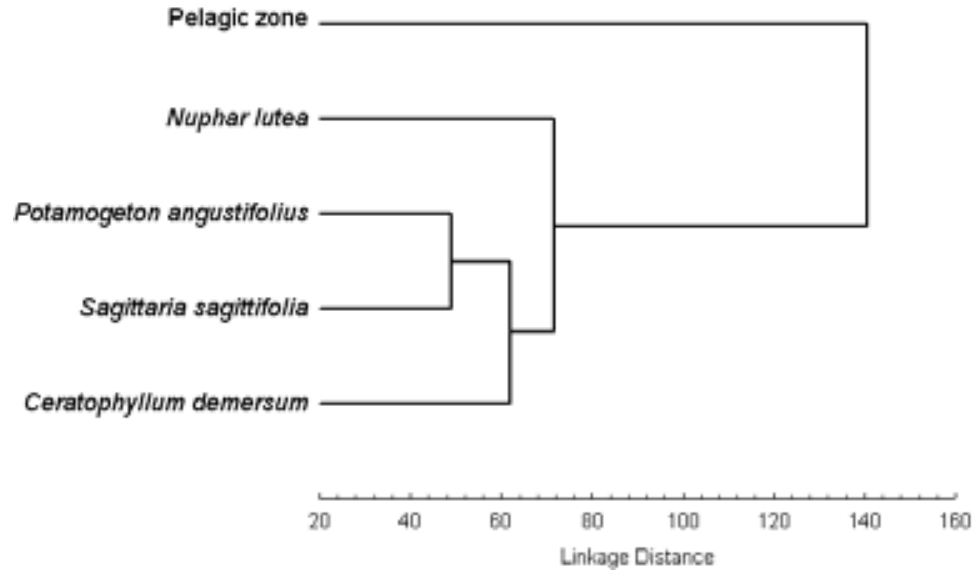

Fig. 3. Cluster analysis on similarity of the communities (phyto-, protozoo- and zooplankton) in Lake Beloe

Table 1: Comparison of plankton in different zones of Lake Beloe in July 2006

\begin{tabular}{|c|c|c|c|c|c|c|c|}
\hline \multirow[b]{2}{*}{ Parameter } & \multirow[b]{2}{*}{$\begin{array}{l}\text { Groups of } \\
\text { plankton }\end{array}$} & \multicolumn{6}{|c|}{ Biotope } \\
\hline & & 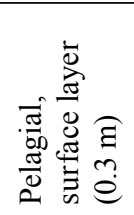 & 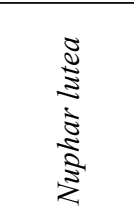 & 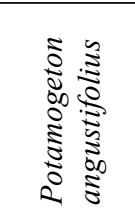 & 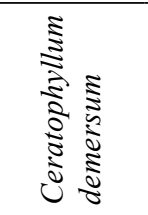 & 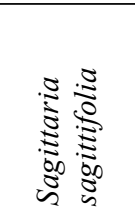 & 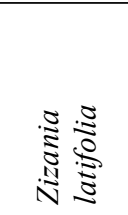 \\
\hline \multirow{3}{*}{ Number of species } & Phytoplankton & 27 & 35 & 69 & 49 & 30 & 33 \\
\hline & Protozooplankton $^{\mathrm{c}}$ & 9 & 24 & 23 & 25 & 34 & n.f. \\
\hline & Zooplankton & n.d. & 22 & n.f. & 44 & 24 & 37 \\
\hline \multirow{3}{*}{$\begin{array}{l}\text { Shannon index, } \\
\mathrm{Ha}^{\mathrm{a}} / \mathrm{Hb}^{\mathrm{b}}\end{array}$} & Phytoplankton & $3.9 / 2.2$ & $3.79 / 2.74$ & $4.76 / 3.38$ & $4.28 / 2.56$ & $1.63 / 3.17$ & $2.64 / 2.40$ \\
\hline & Protozooplankton & $1.8 / 1.6$ & $2.55 / 3.34$ & $2.11 / 3.24$ & $1.99 / 1.94$ & $2.83 / 3.42$ & n.f. \\
\hline & Zooplankton & n.d. & $3.0 / 2.56$ & n.f. & $4.59 / 3.86$ & $4.17 / 3.26$ & $4.18 / 3.01$ \\
\hline \multirow{3}{*}{ Pielou index, E } & Phytoplankton & 0.82 & 0.74 & 0.78 & 0.76 & 0.33 & 0.52 \\
\hline & Protozooplankton & 0.57 & 0.56 & 0.47 & 0.43 & 0.56 & n.f. \\
\hline & Zooplankton & n.d. & 0.67 & n.f. & 0.84 & 0.91 & 0.80 \\
\hline \multirow{3}{*}{ Abundance, ind./L } & Phytoplankton & 1896000 & 1952000 & 6316000 & 3560000 & 4840000 & 4588000 \\
\hline & Protozooplankton & 1006.5 & 1079.1 & 5349.3 & 30610.8 & 9810.9 & n.f. \\
\hline & Zooplankton & n.d. & 266.8 & n.f. & 469.2 & 702 & 651.8 \\
\hline \multirow{3}{*}{ Biomass, $\mathrm{mg} / \mathrm{m}^{3}$} & Phytoplankton & 1642.2 & 1868.6 & 8006.6 & 7873.1 & 1037.5 & 5910.3 \\
\hline & Protozooplankton & 35 & 19.9 & 55.9 & 457.8 & 116.2 & n.f. \\
\hline & Zooplankton & n.d. & 1583.8 & n.f. & 3218.2 & 20745.4 & 11324.9 \\
\hline
\end{tabular}

n.d. - not determined

n.f. - not found

${ }^{a}$ Shannon index calculated based on abundance

${ }^{\mathrm{b}}$ Shannon index calculated based on biomass

${ }^{\mathrm{c}}$ Protozooplankton $=$ Ciliates 
Pseudoanabaena limnetica (Lemmermann)

Komárek (14 \% of total abundance) and Eudorina elegans Ehrenberg (12 \%). In zooplankton community from $C$. demersum, $94 \%$ of total abundance was presented by subdominants, while dominants were absent. The maximum Shannon index for ciliates $(\mathrm{Hn}=2.83 ; \mathrm{E}=0.56)$ was registered in S. sagittifolia zone (Table 1).

Characteristics of general quantity parameters of planktonic community

Maximum total abundance $\left(4.85 \times 10^{6}\right.$ ind./L) and biomass $(21.89 \mathrm{mg} / \mathrm{L})$ for phyto-, protozooand zooplankton (from macrophyte association of three different ecotypes: $N$. lutea, $C$. demersum and $S$. sagittifolia) were registered for the zone of S. sagittifolia. Maximum total number of species (118 species) was registered for planktonic community in $C$. demersum. Maximum numbers of plankton species were registered in different biotopes: for phytoplankton and zooplankton - in submerged rooted hydrophytes zone; for ciliates in low-grasses helophyte zone (Table 1). High abundance and biomass of plankton in submerged rooted plants communities was noticed previously (Bykova et al., 2009; Mukhortova, 2008; Tarasova, 2008; Unkovskaya et al., 2010). It is explained by (1) presence of a suspended organic matter and fine detritus, (2) better protection from waves and wind, (3) diversity of local niches etc. Maximum value of zooplankton abundance in S. sagittifolia was caused by a great number of nauplii there. Minimum number of species (81), total abundance (1.95 x $10^{6}$ ind./L) and total biomass $(3.47 \mathrm{mg} / \mathrm{L})$ were registered in $N$. lutea zone. It's interesting that species inhabiting this zone were similar to those in pelagic zone, because the $N$. lutea forms the most "pelagic" zone of macrophytes. As it is also known, this plant extracts the alkaloid nupharin, depressing the development of cyanophyta (Lauridsen et al., 1997; Zimbalevskaya, 1981). Furthermore, broad leaves of $N$. lutea reduce the light penetration to the water column and due to this unfavorable for the phytoplankton. Lack of available food decreases number of protozoan (ciliates) and metazoan plankton species.

\section{Structure of plankton in different zones}

Chlorophyta was the only group dominating in phytoplankton of all zones in 2006 (Table 2). The abundance of Chlorophyta was maximum in the pelagic zone and in the $Z$. latifolia zone that was correlated with the complete absence of cyanobacteria there. However the dominants inside the group were different in different zones: Eutetramorus planctonicus (Korsch.) Bourrelly (19.4\% of total abundance) and Eudorina elegans Her. (18.1\%) in pelagic zone; E. planctonicus was absent in $Z$. latifolia, while abundance of $E$. elegans was $54 \%$ of total.

Phytoplankton in 2006 was characterized by a lack of cyanoprokaryota in pelagic zone and its maximum ability ( $76 \%$ of total abundance) in $S$. sagittifolia community due to a single species, Microcystis pulverea (Wood) Forti emend. Elenk. In Kuibyshev reservoir, a large water body located near Lake Beloe, M. pulverea causes water blooms. We assume that in Lake Beloe bloom of $M$. pulverea probably started to develop just in a warm, shallow zone of Sagittaria community. However due to the fact that small-celled Microcystis (cell diameter $1 \mu \mathrm{m}$; colony diameter - less than $20 \mu \mathrm{m}$ ) was probably consumed by nauplii (Jeppesen et al., 1992; Kerfoot et al., 1988; Kryuchkova, 1989), this bloom did not spread. In other macrophyte communities, blue-green algae were presented by attached forms Oscillatoria, Lyngbia, Phormidium etc., which could be a food for secondary filterers, cladocerans. The number of attached algae was especially high in the plankton inhabiting macrophytes having broad leaves $(S$. sagittifolia, N. lutea). 


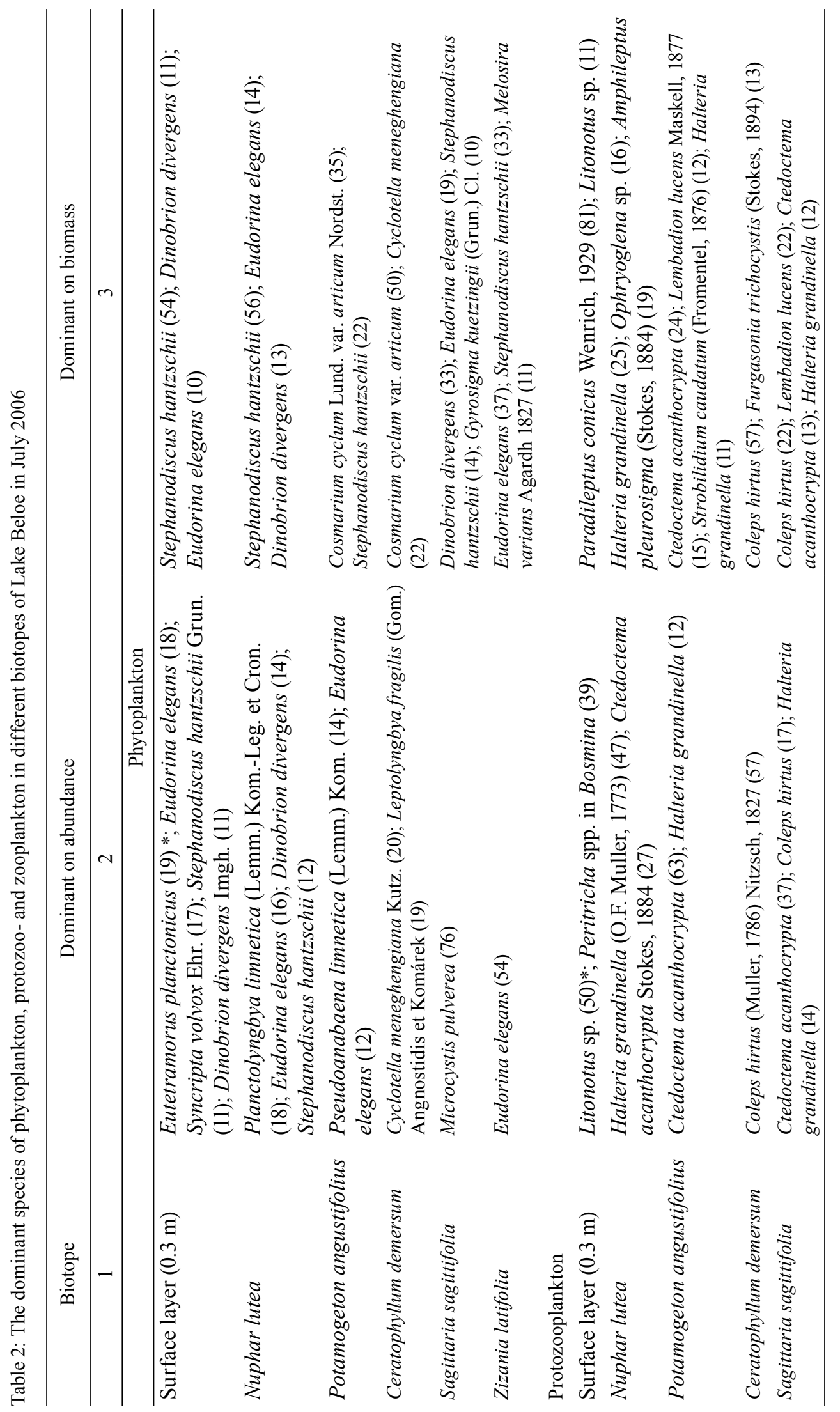




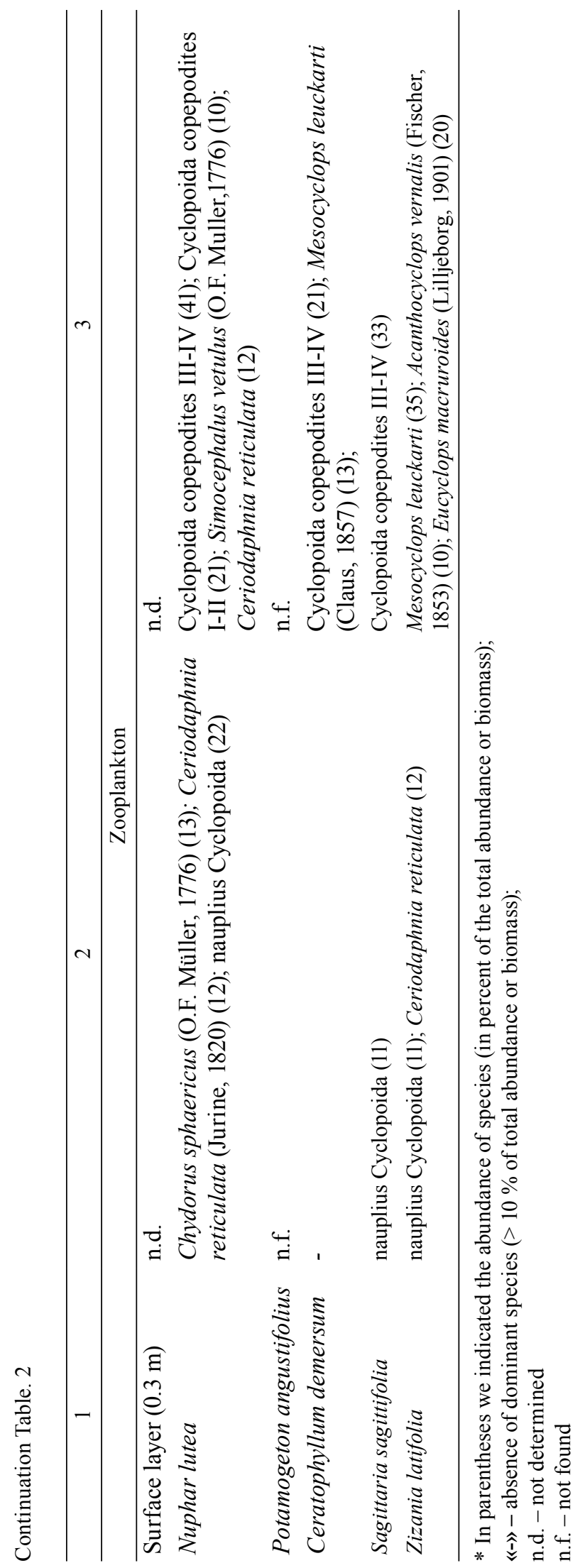


Another peculiarity of the plankton of Lake Beloe in 2006 was a relatively high number of Rotifera in pelagic zooplankton (44\%) comparing with littoral community (11-24\%). Our results are in a good agreement with those by O.Yu. Derevenskaya (2002), who also found high abundance of Rotifera in the pelagic zone of Lake Beloe. As Rotiferia prefer more eutrophic conditions, we can propose that in the littoral zone macrophytes adsorb the organic particles from the water, but there is a lot of fine detritus on the leaves surface. It could be regarded as explanation of high number of the sessile rotifers Rotaria neptunia (Ehrenberg, 1832), $R$. rotatoria rotatoria (Pallas, 1766), Dissotrocha aculeata aculeata (Ehrenberg, 1832) and scrapping crustaceans (Pleuroxus truncatus (O.F. Müller, 1785), P. aduncus (Jurine, 1820), Chydorus sphaericus (O.F. Müller, 1785), C. ovalis Kurz, 1875, Alona intermedia Sars, 1862, Alona rectangula Sars, 1861) occasionally present in plankton samples. These species generally are filterers. They were washed out from the floating leaves of Nuphar lutea and gave about $94 \%$ of "plankton" abundance. In zooplankton inhabiting other macrophytes (Typha latifolia, Zizania latifolia, Sagittaria sagittifolia, Ceratophyllum demersum, Elodea Canadensis and Potamogeton angustifolius) and in the pelagic zooplankton the percentage of filterers was lower (68-80\% of total abundance) and the role of predators (Mesocyclops leuckarti (Claus, 1857), Thermocyclops oithonoides (Sars G.O., 1862), Eucyclops macruroides (Lilljeborg, 1901), Microcyclops varicans (Sars G.O., 1863)) was more considerable. Some authors (Lauridsen et al., 1997; Zimbalevskaya, 1981) observed similar distribution of filterers and predators in zooplankton community.

Ciliate community was characterized by the dominance of predators in pelagic plankton $(54 \%$ of total number and $92 \%$ of total biomass). In macrophyte zone, besides bacteriodetritophages, the dominants in the plankton were hystophages of genera Coleps and Ophryoglena ( $76 \%$ of the total abundance of ciliates in C. demersum), which consume decomposing plant tissues and even being predators. Probably, the degradation processes are more intensive in the $C$. demersum zone. In contrast, in Lake Raifskoe, located close to Lake Beloe, the predators are found only in plankton from macrophyte zone (Bykova, Zharikov, 2009). The reason of such differences is not obvious.

As a result of PCA analysis based on stand density index for all three groups of plankton from macrophyte association of three various zones (N. lutea, C. demersum and S. sagittifolia), we selected 2 groups which included species from phytoplankton, protozooplankton and zooplankton, corresponding to the first two principal components (Tabl 3). The selected two principal components describe more than $80 \%$ of variability of structure of community. Probable, grouping factors for PCA axis were trophical preferences of protozooplankton and zooplankton depending on size.

The first principal component $(61.57 \%$ of variance explained of structure of community) contained colonial species of phytoplankton: Dinobrion divergens Imgh., Aulacoseira subarcticaca (O. Müller) Hawoath, Fragilaria virescens Ralfs, Eudorina cylindrica Korsch., Pediastrum duplex Meyen.; small copepods: Metacyclops gracilis gracilis (Lilljeborg, 1853) and cladocerans: Ceriodaphnia reticulate (Jurine, 1820), C. pulchella Sars, 1862, Alona rectangula Sars, 1862 (Fig. 4). This combination is explained by the fact that the large-sized colonial algae are more protected from the grazing by small zooplankton, which prefers protozoans from the same group: C. hirtus, C. hirtus viridis Ehrenberg, 1831, Furgasonia trichocystis (Stokes, 1894), Lembadion bullinum Perty, 1852, Strobilidium caudatum (Fromentel, 1876). 
Table 3: Result of the Principal Components Analysis (PCA) for planktonic species, their interset correlation coefficients $(r)$ with PCA axes, eigenvalue and the percentage of variance explained by the first two components for planktonic community in the Lake Beloe in July 2006. Only species with $|r|>0.9$ are presented.

\begin{tabular}{|c|c|c|c|}
\hline Species & Abbreviation & PCA Axis 1 & PCA Axis 2 \\
\hline \multicolumn{4}{|c|}{ Phytoplankton } \\
\hline Microcystis pulverea (Wood) Forti emend. Elenk. & $\mathrm{aMp}$ & -0.178 & 0.984 \\
\hline Aulacoseira subarctica (Müller) Haworth & $\mathrm{aAsu}$ & 0.971 & -0.239 \\
\hline Crucigenia tetrapedia (Kirchner) W. et G. S. West & $\mathrm{aCte}$ & -0.178 & 0.984 \\
\hline Dinobryon divergens Imhof & $\mathrm{aDd}$ & -0.995 & -0.096 \\
\hline Eudorina cylindrica Korshikov & aEcy & 0.941 & -0.338 \\
\hline Fragilaria crotonensis Kitton & $\mathrm{aFcr}$ & -0.084 & -0.996 \\
\hline Fragilaria virescens Ralfs & aFvi & 0.941 & -0.338 \\
\hline Gomphonema parvulum Kützing & aGpa & 0.303 & -0.953 \\
\hline Kephyroin moniliferum (Schmid) Bourrelly & $\mathrm{aKm}$ & -0.178 & 0.984 \\
\hline Pandorina morum (Müller) Bory & aPmo & 0.999 & -0.019 \\
\hline Pediastrum duplex Meyen & $\mathrm{aPdu}$ & 0.999 & 0.027 \\
\hline Scenedesmus denticulatus Lagerheim & aSde & -0.178 & 0.984 \\
\hline Scenedesmus armatus Chodat & aSar & -0.134 & -0.991 \\
\hline Trachelomonas volvocina Ehrenberg & aTvo & -0.283 & -0.959 \\
\hline \multicolumn{4}{|c|}{ Protozooplankton } \\
\hline Coleps hirtus (Muller) Nitzsch & cChi & 0.988 & -0.153 \\
\hline Coleps hirtus viridis Ehrenberg & $\mathrm{cChv}$ & 0.957 & -0.289 \\
\hline Furgasonia trichocystis (Stokes) & $\mathrm{cFtr}$ & 0.956 & -0.292 \\
\hline Lembadion bullinum Perty & cLbu & 0.941 & -0.338 \\
\hline Limnostrombidium viride (Stein) & cLvi & -0.178 & 0.984 \\
\hline Oxytricha sp. & cOse & -0.178 & 0.984 \\
\hline Pelagostrombidium fallax (Zach.) & cPel & -0.178 & 0.984 \\
\hline Stentor roesili Ehrenberg & cSroe & -0.178 & 0.984 \\
\hline Strobilidium caudatum (Fromentel) & cScau & -0.982 & -0.188 \\
\hline \multicolumn{4}{|c|}{ Zooplankton } \\
\hline Asplanchna priodonta Gosse & zApr & -0.178 & 0.984 \\
\hline Alona rectangula Sars & zAre & 0.941 & -0.338 \\
\hline Alona intermedia Sars & zAin & -0.263 & -0.965 \\
\hline Ceriodaphnia pulchella Sars & $\mathrm{zCpu}$ & 0.991 & -0.131 \\
\hline Ceriodaphnia reticulata (Jurine) & $\mathrm{zCre}$ & -0.999 & -0.044 \\
\hline Daphnia cucullata Sars & $\mathrm{zDcu}$ & -0.178 & 0.984 \\
\hline Eucyclops macruroides (Lilljeborg) & zEma & -0.178 & 0.984 \\
\hline Mesocyclops leuckarti (Claus) & zMle & 0.284 & 0.959 \\
\hline Microcyclops gracilis (Lilljeborg) & $\mathrm{zMgr}$ & 0.941 & -0.338 \\
\hline Sida crystallina (Müller) & zScr & 0.117 & 0.993 \\
\hline Eigenvalue & & 3.16 & 1.27 \\
\hline Variance explained, \% & & 61.57 & 24.75 \\
\hline
\end{tabular}




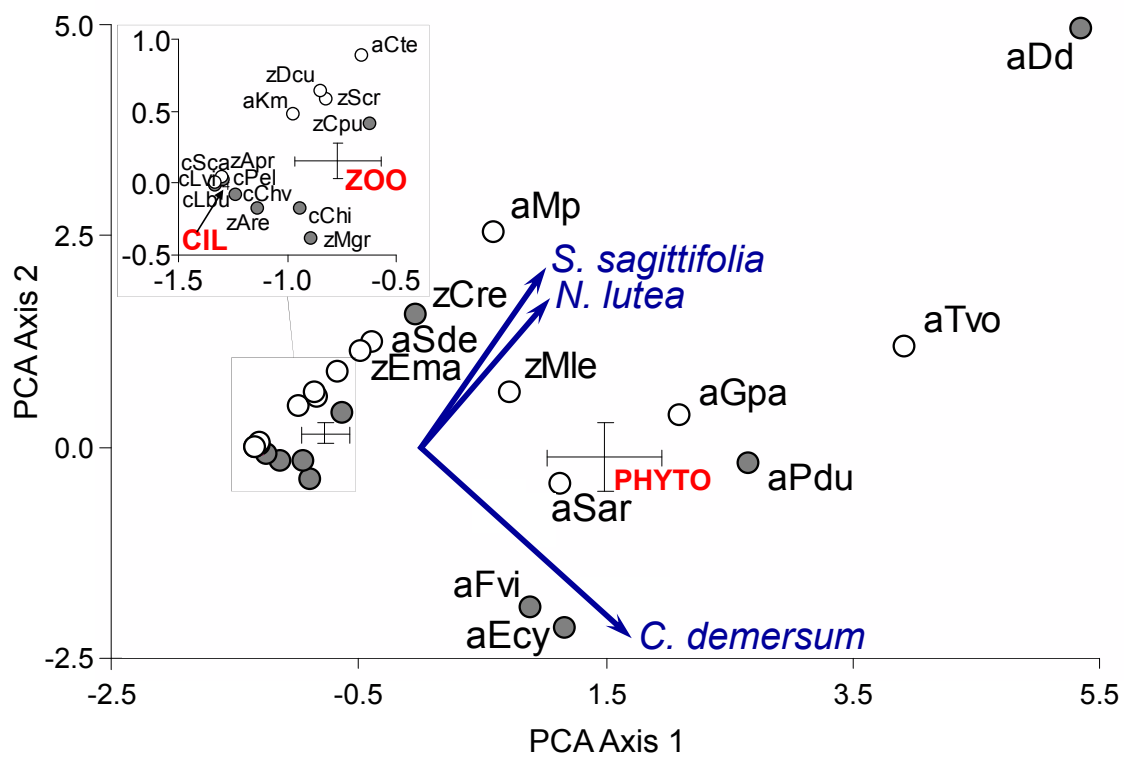

Fig. 4. Principal component analysis biplot of ordination between planktonic community and different biotopes of Lake Beloe in July 2006. Plot of centroids (mean) of clouds distributions of the plankton community and some plankton species (species abbreviations are given in Table 3) in the space of the first and second PCA axis; \pm $95 \%$ confidence interval. Grey circles - species most correlated $(|r|>0.9)$ with the first principal component, open circles - with the second principal component. PHYTO - phytoplankton, CIL - protozooplankton, ZOO zooplankton

The second principal component $(24.75 \%$ of variance explained of structure of community) included small-sized solitary algae or smallsized colonial algae: M. pulverea, Kephyrion moniliferum (Schmid) Bourrelly, Gomphonema parvulum Kütz. var. parvulum, Trachelomonas volvocina Ehr., Crucigenia tetrapedia (Kirchn.) W. et G.S. West, Scenedesmus armatus Chrod. var. armatus, S. denticulatus Lagerh. var. linearis Hansg (Fig. 4). The listed above forms are bad food for the large forms of zooplankton also included to the same group: Asplanchna priodonta Gosse, 1850, Sida crystallina crystallina (O.F. Müller, 1776), Daphnia cucullata Sars, 1862, Eucyclops macrurus (Sars G.O., 1963), Mesocyclops leuckarti (Claus, 1857). Algophages and non-selective omnivorous ciliates were also in the same group: St. roeseli Ehrb., 1835, Oxytricha sp., Limnostrombidium viride (Stein, 1867), Pelagostrombidium fallax (Zach., 1895).
They were associated mainly with a community of $S$. sagittifolia and able to consume fine phytoplankton. Obviously, zooplankton in both cases prefers to consume medium-sized algae and ciliates (Nurminen, Horppila, 2002; Gulati, DeMott, 1997 et al.)

Our study has demonstrated that plankton of macophyte zone is characterized by a high species diversity and peculiarity of all groups as compared with pelagic zone of Lake Beloe.

Maximum total abundance and biomass of plankton (phyto-, protozoo-, and zooplankton) were registered in the zone of $S$. sagittifolia, maximum number of species was registered in the zone of $C$. demersum. However maximums of different plankton groups were registered in different zones: phytoplankton and ciliates - in submerged rooted hydrophytes (C. demersum, P. angustifolius); zooplankton - in zone of lowgrasses helophytes (S. sagittifolia). Minimum 
abundance, biomass and Shannon index is registered in the zone of plants with floating leaves

(N. lutea) because of inhibition by nupharin, shadowing and closeness to pelagic zone.

We have not found any strong differences in the species composition of zoo- and phytoplankton between littoral zones covered by different macrophytes. However there were differences between the pelagic and littoral plankton: the absence of Cyanophyta in pelagic plankton; higher percentage of rotifers in pelagic zone as compared with littoral zooplankton; the presence of predaceous ciliates as a part of pelagic community, and the presence of hystohpages as a part of the littoral plankton community.

The peculiarity of our study is finding specific character of planktonic community organisms (protozoo-, zoo- and phytoplankton) in phytal zone of Lake Beloe, its comparing with pelagic complex of organisms and determining of its contributing factors.

\section{Conclusion}

Phytophilous flora and fauna play a significant role in species diversity development in planktonic community of the lake, and communities of planktonic organisms forming in various ecotopes are characterized by high species diversity. Differences in components of planktonic community developing in the pelagic part of the lake and in individual macrophyte species are more significant than differences between macrovegetation plankton communities. Reaction of different planktonic community groups (phyto-, zoo-, ciliaplankton) to conditions in different ecotopes is similar in spite of peculiar properties of their biology and organization.

\section{Acknowledgments}

We express our deep gratitude to Gorshkov Yu.A., the director of the Volzhsko-Kamskiy Biosphere Natural State Reserve, for his assistance in organizing and carrying out works on the territory of the Biosphere Reserve. We thank V.M. Zhdanova for help in translating the manuscript and for valuable advice.

This work was supported by the Russian Foundation for Basic Research (project № 15-3450235).

\section{References}

1. Balushkina E.V., Vinberg G.G. (1979) The relationship between length and weight of planktonic crustaceans. In: Experimental and field studies of the biological basis of productivity of lakes. Leningrad: Publishing House of the Zool. Institute of the USSR Academy of Sciences, p. 58-72. (in Russian).

2. Barko J.W., James W.F. (1998) Effects of submerged aquatic macrophytes on nutrient dynamics, sedimentation and resuspension. In: E. Jeppesen, Ma. Søndergaard, Mo. Søndergaard, K. Christoffersen (Eds.) The structuring role of submerged macrophytes in lakes. Ecological Studies, 131. New York: Springer Verlag, p. 197214.

3. Belova I.V. (1998) Species composition and ecological peculiarities of Ciliophora in the river Moscow. Zoological Journal 77 (12): 1349-1356. (in Russian).

4. Bykova S.V. (2009) The ciliates of plankton pelagic zone and macrovegetation of reserved lakes Raifskoje and Ilantovo. Materials of VI International research and practice conference «Tatischev readings: actual problems of science and practice». Toglyatti, p. 17-25. (in Russian). 
5. Bykova S.V., Zharikov V.V. (2009) The ciliates of Lake Raifskoje (Volzhsko-Kamskiy state biosphere reserve). Samarskaja Luka: problems of regional and global ecology 18 (3): 121-131. (in Russian).

6. Chatton E., Lwoff A. (1936) Techniques pour letude des Protozoaires, specialement de leurs structures superficielles (cinetome et argyrome). Bull. Soc. France Microsc. 5: 25-39.

7. Corliss J.O. (1979) The Ciliated protozoa characterization, classification and guide to the literature. Second Edition. Oxford Press, p. 189-326.

8. Curds C.R. (1982) British and other freshwater ciliated protozoa. Part I Ciliophora: Kinetofragminophora. Keys and notes for the identification of the free-living genera. Cambridge University Press, $387 \mathrm{p}$.

9. Curds C.R., Gates M.A., Roberts D.VcL. (1983) British and other freshwater ciliated protozoa. Part II. Ciliophora: Oligohymenophora and Polyhymenophora. Keys and notes for the identification of the free-living genera. Cambridge University Press, $473 \mathrm{p}$.

10. Dale H.M. (1986) Temperature and light: the determining factor in maximum depth distribution of aquatic macrophytes in Ontario, Canada. Hydrobiologia 133: 73-77.

11. Dedyu I.I. (1989) Ecological Encyclopedic dictionary. Kishinyov, 408 p. (in Russian).

12. Derevenskaya O.Yu., Unkovskaya E.N., Mingazova N.M., Pavlova L.R. (2002) Structures of zooplankton communities of lakes in Raifa part of Volzhsko-Kamaskiy Reserve and its buffer zone. Transactions of Volzhsko-Kamskiy National Nature Reserve, vol. 5. Kazan, p. 52-70. (in Russian).

13. Duarte C.M., Kalff J., Peters R.H. (1986) Pattern in biomass and cover of aquatic macrophytes in lakes. Can. J. Fish. Aquat. Sci. 43: 1900-1908.

14. Ettl H. (1983) Chlorophyta. Phytomonadina. Susswasserflora von Mitteleuropa. Jena, 807 p.

15. Ettl H., Gartner G. (1983) Chlorophyta. Tetrasporales, Chlorococcales, Gloedendrales. Susswasserflora von Mitteleuropa. Jena, 436 p.

16. Ettl H., Zerloff G., Heynig H., Mollenhauer D. (1990) Dinophyceae (Dinophlagellida). Susswasserflora von Mitteleuropa. Jena, 448 p.

17. Fairchild G.W. (1981) Movement and microdistribution of Sida crystallina and other littoral microcrustacea. Ecology 62: 1341-1352.

18. Foissner W., Berger H., Schaumdurg J. (1999) Identification and ecology of limnetic plancton ciliates. Informationsberichte des Bayer, Landesamtes für Wasserwirtschaft, Munchen, 793 p.

19. Foissner W., Blatterer H., Berger H., Kohmann F. (1991) Taxonomiche und okologische Revision der Ciliaten des Saprobiensystems. 1: Cyrtophorida, Oligotrichida, Hypotrichida, Colpodea. Informationsberichte des Bayer, Landesamtes fur Wasserwirtschaft, Munchen, $478 \mathrm{p}$.

20. Gulati R.D., DeMott W.R. (1997) The role of food quality for zooplankton: remarks on the stateof-the-art, perspectives and priorities. Freshwater Biol. 38: 753-768.

21. Hellawell I.M. (1986) Biological indicators of fresh-water pollution and enviromental management. London, New-York, 546 p.

22. Horppila J., Nurminen L. (2001) The effect of an emergent macrophyte (Typha angustifolia L.) on sediment resuspension in a shallow north temperate lake. Freshwat. Biol. 46: 1447-1455.

23. Horppila J., Nurminen L. (2003) Effects of submerged macrophytes on sediment resuspension and internal phosphorus loading in Lake Hiidenvesi (southern Finland). Wat. Res. 37: 4468-4474. 
24. Husted F. (1939) Systematische und öklogische Untersuchungen sber die Diatomeenflora von Yova, Bali und Sumatra. Das Phytoplankton Susswassers. Arch. Hydrobiol. 16: 326 p.

25. Jeppesen E., Lauridsen T.L., Kairesalo T., Perrow M. (1998) Impact of submerged macrophytes on fish-zooplankton interactions in lakes. In: E. Jeppesen, Ma. Søndergaard, Mo. Søndergaard, K. Christoffersen (eds.) The structuring role of submerged macrophytes in lakes. Ecological Studies, Springer Verlag 131: 91-114.

26. Jeppesen E., Sortkjaer O., Søndergaard M., Erlandsen M. (1992) Impact of a trophic cascade on heterotrophic bacterioplankton production in two shallow fish-manipulated lakes. Arch. Hydrobiol. Beih. Ergebn. Limnol. 37: 219-231.

27. Kahl A. (1930-1935) Urtiere oder Protozoa. Wimpertiere oder Ciliata (Infusoria), Die Tierwelt Deutschlands. Teil. 18, 21, 25, 30. Jena, 886 p.

28. Karabin A. (1985) Pelagic zooplankton (Rotatoria + Cladocera) variation in the process of lake eutrophication. I. Structural and quantitative features. Ekol. Pol. 33 (4): 567-616.

29. Kerfoot C.W., Levitan C., DeMott W.R. (1988) Daphnia-phytoplankton interactions: densitydependent shifts in resource quality. Ecology 69: 1806-1825.

30. Komarek J., Anagnostidi K. (2000) Cyanoprocariota. Teil 1: Chroococcales. Susswasserflora von Mitteleuropa. Jena, Stuttgard, $643 \mathrm{p}$.

31. Kouzmin V.Y. (1984) Tables for calculating the biomass of algae. Magadan, 48 p. (in Russian).

32. Krammer K., Lange-Bertalot H. (1988) Baciilariophyceae. Teil 2: Bacillariaceae, Epithemiaceae, Surirellaceae. Susswasserflora von Mitteleuropa. Jena, 596 p.

33. Krammer K., Lange-Bertalot H. (1991 a) Baciilariophyceae. Teil 3: Centrales, Fragilariaceae, Eunotiacaea. Susswasserflora von Mitteleuropa. Jena, 576 p.

34. Krammer K., Lange-Bertalot H. (1991 b) Bacillariophyceae. Teil 4: Achnanthaceae, Kritische Frganzunger zu Navicula (Lieolatae) ung Gomphonema. Geamliteraturverzeichnis, Susswasserflora von Mitteleuropa. Jena, $437 \mathrm{p}$.

35. Krammer K., Lange-Bertalot H. (1986) Baciilariophyceae. Teil 1: Naviculaceae. Susswasserflora von Mitteleuropa. Jena, $876 \mathrm{p}$.

36. Kryuchkova N.M. (1989) Trophic interworking of zoo- and phytoplankton. Moscow: Nauka, 124 p. (in Russian).

37. Kutikova L.A. (1970) Rotifer fauna of the USSR (Rotatoria). Subclass Eurotatoria (units Ploimida, Monimotrochida, Paedotrochida). Leningrad, 744 p. (in Russian).

38. Kutikova L.A. (2005) Bdelloid rotifer fauna of Russia. M.: Association of Scientific Publications KMK, 315 p. (in Russian).

39. Lauridsen T., Jeppesen E., Mitchell S.T., Lodge D.M., Burks R.L. (1999) Diel variation in horizontal ditribution of Daphnia and Ceriodaphnia in oligotrophic and mesotrophic lakes with contrasting fish densities. Hydrobiologia 408/409: 241-250.

40. Lauridsen T.L., Jeppesen E., Søndergaard M., Lodge D. (1997) Horizontal migration of zooplankton: Predator-mediated use of macrophyte habitat. In: E. Jeppesen, Ma. Søndergaard, Mo. Søndergaard, K. Christoffersen (eds.), The structuring role of submerged macrophytes in lakes, Ecological Studies, Springer Verlag, New York, 131: 233-239.

41. Lodge D.M. (1991) Herbivory of freshwater macrophytes. Aquat. Bot. 41: 195-224.

42. Mamaeva N.V. (1979) Ciliates of the Volga Basin. Leningrad: Nauka, 150 p. (in Russian). 
43. Manuylova E.F. (1964) Cladocerans (Cladocera) of the USSR, Moscow: Nauka, 326 p. (in Russian).

44. Middelboe A.L., Markager S. (1997). Depth limits and minimum light requirements of freshwater macrophytes. Freshw. Biol. 37: 553-568.

45. Morduhay-Boltovskoy F.D. (1954) Proceedings of the average weight of aquatic invertebrates of the Don Basin. In: Problems of hydrobiology of inland waters: tr. problems and subject areas. Workshop. Leningrad: Zoological Institute, 2: 223-241. (in Russian).

46. Mukhortova O.V. (2008) Zooplankton community of pelagic zone and macrovegetation in diverse basins of Middle and Lower Volga. Dis. can. biol. Sciences, Toglyatti, 21 p. (in Russian).

47. Nabivaiylo Yu.V., Titlyanov E.A. (2006) Competitive interactions of algae in nature and in culture. Marine Biology 32 (5): p. 315. (in Russian).

48. Nurminen L. (2003) Macrophyte species composition reflecting water quality changes in adjacent water bodies of lake Hiidenvesi, SW Finland. Ann. Bot. Fennici 40: 199-208.

49. Nurminen L., Horppila J. (2002) A diurnal study on the distribution of filter feeding zooplankton: Effect of emergent macrophytes, $\mathrm{pH}$ and lake trophy. Aquat. Sci. 64: 198-206.

50. Nurminen L., Horppila J., Tallberg P. (2001) Seasonal development of the cladoceran assemblage in a turbid lake: the role of emergent macrophytes. Arch. Hydrobiol. 151: 127-140.

51. Odum E. (1975) Basic Ecology. M.: World, 740 p. (in Russian).

52. Orlova-Bienkowskaja M.Y. (2001) Cladocera: Anomopoda (Daphniidae: genus Simocephalus). Leiden: Backhuys Publ., Bd. 17, 130 p.

53. Papchenkov V.G. (2006) Different approaches to the plants classification of basins and water channels. Proceedings of the VI conference on aquatic macrophytes «Hydrobotany 2005». Rybinsk: Rybinsk Printing House, p. 16-24. (in Russian).

54. Persson L. (1991) Behavioural response to predators reverses the outcome of competition between prey species. Behav. Ecol. Sociobiol. 28: 101-108.

55. Phytoplankton of Lower Volga. (2003) Reservoirs and lower reaches of the river. St. Petersburg: Science, 231p. (in Russian).

56. Popovsky J., Pfiester L. (1990) Dinophyceae (Dinoflagellata). Susswasserflora von Mitteleuropa. Jena, $272 \mathrm{p}$.

57. Pratt J.R., Cairns J.Jr. (1985) Functional groups in the protozoa: roles in different ecosystems. J. Protozool. 32: 415-423.

58. Research methods of geobiocoenosis of inland water basins. (1975) Moscow: Nauka, 240 p. (in Russian).

59. Scheffer M., de Redelijkheid M.R., Noppert F. (1992) Distribution and dynamics of submerged vegetation in a chain of shallow eutrophic lakes. Aquat. Bot. 42: 199-216.

60. Scheffer M., Hosper S.H., Meijer M-L., Moss B. (1993) Alternative equilibria in shallow lakes. TREE 8: 275-279.

61. Schindler D.E., Carpenter S.R., Cottingham K.L., He X., Hodgson J.R., Kitchell J.F., Soranno P.A. (1996) Food web structure and littoral zone coupling to pelagic cascades. In: Polis G.A., Winemiller K.O. (eds.) Food webs: integration of pattern and dynamics. New York: Chapman, Hall, p. 96-108. 
62. Schriver P., Bøgestrand J., Jeppesen E., Søndergaard M. (1995) Impact of submerged macrophytes on fish-zooplankton-phytoplankton interactions: Large-scale enclosure experiments in shallow eutrophic lake. Freshw. Biol. 33: 255-270.

63. Semenchenko V.P. (2008) Role of macrophytes in the variability of zooplankton community structure in the littoral zone of shallow lakes. Contemporary Problems of Ecology 1 (2): 257-262.

64. Small E.B., Lynn D.H. (1985) Phylum Ciliophora Doflein, 1901, An Illustrated guide to the Protozoa. Kansas: Allen Press, p. 373-575.

65. Small E.B., Lynn D.H. (2000) Phylum Ciliophora Doflein, 1901, An Illustrated guide to the protozoa. Second edition. Kansas: Allen Press, p. 371-675.

66. Smirnov N.N. (1976) Chydoridae of the world fauna. In the series: The fauna of the USSR, vol. 1. Leningrad, 237 p. (in Russian).

67. Smirnov N.N. (1996) Cladocera: the Chidorinae and Sayciinae (Chydoridae) of the World. Belgium, 204 p. (in Russian).

68. Starmach K. (1985) Chryzophyceae und Hantophyceae. Susswasserflora von Mitteleuropa. Jena, Stuttgard, $515 \mathrm{p}$.

69. Systematik und Biologie. (1983) Stuttgard, 1044 p. (in Russian).

70. Tarasova N.G. (2008) Alga of biocenoses of the higer water plants of lakes in Volzhsko-Kamskij reserve. Natural heritage of Russia in 21 century. Proceedings of II international research and practice conference. Ufa, p. 380-385. (in Russian).

71. Timms R.M., Moss B. (1984) Prevention of growth of potentially dense phytoplankton populations by zooplankton grazing in the presence of zooplanktivorous fish in a shallow wetland ecosytem. Limnol. Oceanogr. 29: 472-486.

72. Toivonen H., Huttunen P. (1995) Aquatic macrophytes and ecological gradients in 57 small lakes in southern Finland. Aquat. Bot. 51: 197-221.

73. Unkovskaia E.N., Zharikov V.V., Bykova S.V., Gorbunov M.Yu., Umanskaya M.V., Tarasova N.G., Mukhortova O.B., Palagushkina O.V., Derevenskaia O.U. (2010) Plankton communities of Lake Raifskoe (Volzhsko-Kamskiy state biosphere reserve). I. Biodiversity of plankton communities of different biotopes of Lake Raifskoe. Proceedings of Samara research center, Russian Academy of Sciences, 12, 1 (5): 380-385. (in Russian).

74. Van DonkE., Gulati R.D.(1995) Transition of a lake to turbid state six years after 37 biomanipulation: Mechanisms and pathways. Wat. Sci. Technol. 32: 197-206.

75. Van Donk E., Otte A. (1996) Effects of grazing by fish and waterfowl on the biomass and species composition of submerged macrophytes. Hydrobiologia 340: 285-290.

76. Van Donk E. (1998) Switches between clear and turbid water states in a biomanipulated lake (1986-1996) The role of herbivory on macrophytes. In: E. Jeppesen, Ma. Søndergaard, Mo. Søndergaard, K. Christoffersen (eds.) The structuring role of submerged macrophytes in lakes. Springer Verlag, New York, Ecological Studies 131: 290-297.

77. Vinberg G.G. (1971) Linear dimensions and weight of animals. Zh. Obshch. Biol. 32 (6): 714-723. (in Russian).

78. Yunkovski A.V. (2007) Phylum of Ciliophora Doflein, 1901. Ciliates. Protist: Manual of Zoology. Part 2. St. Petersburg: Science, p. 371-993. (in Russian). 
79. Zharikov V.V. (1996) Cadastre of free living ciliates of Volga reservoirs. Tolyatti, 76 p. (in Russian).

80. Zimbalevskaya L.N. (1981) Phytophilous invertebrates of lowland rivers and reservoirs (ecological sketch). Kiev: Nauk. dumka, 216 p. (in Russian). 